\section{Uji Aktivitas Antimikroba Ekstrak Daun Mahkota Dewa (Phaleria macrocarpa) dengan Metode Difusi Cakram}

\section{Fiqriansyah Wahab', Yustika Indahsari ${ }^{2}$, Nurdiana3, Andi Maghfira Manggabarani4, \& Putri Bella Aulia Nur ${ }^{5}$}

Program Studi Biologi

Universitas Negeri Makassar

Email:wahabfiqriansyah@gmail.com

Abstract. Indonesia has abundant biological rich potential so it needs to be researched and utilized especially for various plants that have potential as medicine. One of the plants that can be used as a medicinal plant and has many benefits is the Phaleria macrocarpa. This study aimed to determine the effectiveness of $P$. macrocarpa leaf extract to inhibit the growth of Escherecia coli and Staphylococcus aureus bacteria. The results showed that the leaf extract of $P$. macrocarpa containing tannin compounds has the ability to inhibit bacterial growth. The extract of the crown of the deity of the god is more effective in inhibiting the growth of $S$. aureus bacteria compared to E. coli bacteria which is shown with a larger inhibitory zone. It means that the extract of the P. macrocarpa can be used as a medicinal ingredient for diseases caused by $S$. aureus bacteria.

Keywords: antimicrobial activity, leaf extract of Phaleria macrocarpa, disc diffusion method

\section{INDONESIAN JOURNAL OF FUNDAMENTAL SCIENCES \\ (IJFS)}

E-ISSN: 2621-6728

P-ISSN: 2621-671X

Submitted: January, $14^{\text {th }} 2020$

Accepted: March, $22^{\text {nd }} 2020$

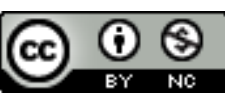

This work is licensed under a Creative Commons Attribution-NonCommercial 4.0 International License 


\section{PENDAHULUAN}

Indonesia memiliki potensi kekayaan hayati yang melimpah sehingga perlu diteliti dan dimanfaatkan khususnya untuk berbagai bahan yang memiliki potensi sebgai obat atau menangkal radikal bebas. Radikal bebas merupakan molekul yang tidak stabil dan sangat reaktif karna mengandung satu atau kebih electron tidak berpasangan sehingga dia akan stabil jika bereaksi dengan molekul lainnya. Radikal bebas dalam tubuh dapat menyerang jaringan tubuh seperti protein dan DNA sehingga dapat menyebabkan pemicu penyakit kaker, penuaan dan penyakit degeneratif lainnya. Senyawa antioksidan dapat meredam reaksi radikal bebas yang bersifat tidak stabil. Antioksidan merupakan senyawa kimia yang dapat menyambungkan satu atau lebih electron pada radikal bebas sehingga menjadi stabil. Dalam kehidupan antioksidan memiliki peran yang positif bagi kesehatan manusia (Agustina, 2017).

Tanaman obat adalah tanaman yang memiliki khasiat obat mengandung zat aktif yang berfungsi mengobati penyakit tertentu atau jika tidak mengandung zat aktif tertentu tapi mengandung efek resultan/sinergi dari berbagai zat yang berfungsi untuk mengobati dan digunakan sebagai obat dalam penyembuhan maupun pencegahan penyakit. Salah satu tanaman yang dapat dijadikan sebagai tanaman obat dan mempunyai banyak khasiat adalah mahkota dewa atau Phaleria macrocarpa (Novitasari, 2016). P. macrocarpa merupakan tanaman yang hidup di daerah tropis. Daun dan buah tumbuhan mahkota dewa merupakan tanaman obat. Secara tradisional mahkota dewa dipakai antara lain sebagai obat untuk penyakit seperti kanker, tumor, diabetes melitus, hepatitis, hipertensi, jantung, rematik, asam urat, alergi, gangguan ginjal, dan ketergantungan obat. Disamping itu juga, digunakan sebagai obat luar untuk penyakit kulit dan kecantikan (Ibrahim, 2010). P. macrocarpa juga banyak digunakan sebagai obat luar dengan cara dioleskan atau dilulurkan. Sedangkan untuk penggunakan sebagai obat dalam, kulit buah, daging dan cangkang buahnya dianjurkan untuk direbus terlebih dahulu karena bersifat toksik. Bijinya sendiri sangat toksik sehingga hanya digunakan sebagai obat luar. Tanaman ini mengandung alkaloid, terpinoid, saponin senyawa resin, polifenol dan flavonoid (Harmita \& Radji, 2008).

P. macrocarpa juga diyakini dapat digunakan sebagai obat untuk penyakit yang disebabkan oleh bakteri. Respon daya hambat pertumbuhan mikroba yang dihasilkan dipengaruhi oleh kandungan senyawa aktif pada P. macrocarpa berupa alkaloid, flavonoid, tanin, dan terpenoid. Senyawa aktif mampu merusak dinding sel yang tersusun atas protein dan lipid sangat rentan terhadap zat kimia yang dapat menurunkan tegangan permukaan. Kerusakan membran sel menyebabkan tergangunya transport nutrisi (senyawa dan ion) sehingga sel bakteri mengalami kekurangan nutrisi yang diperlukan bagi pertumbuhannya sehingga menyebabkan kematian sel. Terjadinya penghambatan mikroba terhadap pertumbuhan koloni bakteri juga disebabkan karena kerusakan yang terjadi pada komponen struktural membran.

Untuk mengidentifikasi suatu zat aktif (senyawa) dalam suatu sampel mula-mula dilakukan ekstraksi. Menurut Susanty \& Bachmid (2016), Ekstraksi pelarut dilakukan dengan cara dingin (maserasi). Proses ekstraksi dengan teknik maserasi dilakukan dengan beberapa kali pengocokan atau pengadukan pada suhu ruang. Tujuan maserasi adalah untuk memberi kesempatan pada simplisia berdifusi ke dalam pelarut dan pelarut yang digunakan adalah etil asetat yang merupakan pelarut dengan toksisitas rendah yang bersifat semi polar sehingga diharapkan dapat menarik senyawa yang bersifat polar maupun nonpolar dari daun P. macrocarpa (Suzery, dkk., 2010). 
Dalam menentukan golongan senyawa yang lebih spesifik dilakukan dengan uji Kromatografi lapis tipis (KLT) yang merupakan salah satu analisis kualitatif dari suatu sampel yang ingin di deteksi dengan memisahkan komponen-komponen sampel pemisahan fisika-kimia dengan fase gerak (larutan pengembang yang cocok), dan fase diam (bahan berbutir) yang diletakkan pada penyangga berupa plat gelas atau lapisan yang cocok. Pemisahan terjadi selama perambatan kapiler (pengembangan) lalu hasil pengembangan di deteksi (Feliana, dkk. 2018). Keuntungan KLT adalah lebih serba guna, cepat, kepekaannya lebih tinggi dan pemisahan komponen senyawa lebih sempurna (Nuria, dkk., 2009). Komponen kimia yang yang dievaluasi dari ekstrak meliputi uji alkaloid, fenol, terpenoid, dan flavonoid (Allen, dkk., 2017).

Untuk memperoleh informasi terkait kemampuan $P$. macrocarpa dalam menghambat pertumbuhan bakteri, maka perlu dilakukan uji efektivitas ekstrak daun $P$. macrocarpa dalam menghambat pertumbuhan bakteri dengan menggunakan bakteri $E$. coli dan S. aureus. Penentuan kadar hambat minimal (KHM) ekstrak terhadap bakteri uji dilakukan dengan metode penipisan lempeng agar. KHM ditentukan berdasarkan konsentrasi ekstrak terkecil yang masih dapat menghambat pertumbuhan pada bakteri (Harmita \& Radji, 2008).

\section{METODE PENELITIAN}

Penelitian ini merupakan penelitian deksriptif yang dilakukan untuk menguji efektivitas ekstrak daun mahkota dewa dalam menghambat pertumbuhan bakteri E. coli dan S. aureus. Penelitian dilakukan pada bulan Oktober 2019 di Laboratorium Mikrobiologi, Jurusan Biologi, fakultas Matematika dan Ilmu Pengetahuan Alam, Universitas Negeri Makassar. Tahapan peneltian melalui dua tahap yakni uji fitokimia dan uji aktivitas anti-mikroba. Uji fitokimia bertujuan untuk mengetahuoi senyawa-senyawa kimia aktif yang ada dalam ekstrak daun mahkota dewa. Sedangkan uji aktivitas antimikroba bertujuan untuk mengetahui kemampuan senyawa kimia tertentu dalam ekstrak daun mahkota dewa untuk menghambat pertumbuhan bakteri.

\section{Uji Fitokimia}

Ekstrak kental etil asetat yang diperoleh pada proses aserasi ditambahkan pereaksi-pereaksi berupa reagen wagner, reagen mayer, $\mathrm{HCl}$ pekat, $\mathrm{FeCl}_{3} 1 \%$, aquades, dan $\mathrm{FeCl}_{3}$ 5\%.

\section{Uji Alkaloid}

Ditimbang 0,1 gram ekstrak simplisia ke dalam tabung reaksi, ditambahkan $10 \mathrm{~mL}$ pelarut etil asetat. Untuk uji alkaloid (wagner) mengambil $2 \mathrm{ml}$ filtrat dari larutan sampel tadi, tambahkan reagen wagner sebanyak $1 \mathrm{ml}$ (Jika terdapat endapan coklat kemerahan, maka ekstrak mengandung alkaloid dengan pereaksi wagner). Tambahkan $1 \mathrm{ml}$ larutan mayer (Jika terbentuk endapan menggumpal berwarna putih yang larut dalam etil, maka ekstrak tersebut mengandung alkaloid dengan perekasi mayer.

\section{Uji Flavonoid}

Mengambil $2 \mathrm{ml}$ filtrat yang telah dilarutkan diawal uji, ditambahkan 0,05 $\mathrm{mg}$ serbuk $\mathrm{Mg}$ dan larutan $\mathrm{HCl}$ pekat sebanyak $1 \mathrm{ml}$, homogenkan. Reaksi positif jika terbentuk warna merah jingga atau warna kunin jingga.

\section{Uji Tanin}

Sampel 0,5 gram dimasukkan ke dalam tabung reaksi, ditambahkan $2 \mathrm{ml}$ etanol 70 $\%$, dikocok untuk dihomogenkan. Kemudian menambahkan 3 tetes $\mathrm{FeCl}_{3} 1 \%$. Reaksi positif jika terbentuk warna hijau kehitaman dan hal tersebut menunjukkan tanin terhidrolisis. 


\section{Uji Saponin}

Sampel mahkota dewa segar, kering dan bertekstur seperti pasta sebanyak 0,5 gram dimasukkan ke dalam tabung reaksi, kemudian menambahkan aquades sebanyak 5 ml. Tabung reaksi tersebut dipanaskan di atas bunsen dan perhatikan ada atau tidak adanya busa stabil. Sampel mengandung saponin jika terbentuk busa stabil dengan ketinggian $1-3 \mathrm{~cm}$ selama 15 menit.

\section{Uji Fenol}

Ditimbang 0,5 gram sampel kemudian dimasukkan ke dalam tabung reaksi, ditambahkan $2 \mathrm{ml}$ etanol 70\%. Kocok agar homogen. Menambahkan 3 tetes $\mathrm{FeCl}_{3}$ 5\%. Reaksi positif jika terbentuk warna hijau atau hijau kebiruan.

\section{Uji Aktivitas Antimikroba}

Medium NA dicairkan menggunakan hotplate, ekstrak sampel ditimbang sebanyak 0,5 gr, enkas disterilisasi menggunakan alkohol, ekstrak yang telah ditimbang dimasukkan ke dalam tabung reaksi, ditambahkan etanol ke dalam tabung reaksi, kemudian dihomogenkan dengan vortex. Medium NA dituang ke dalam cawan petri sambil didekatkan pada bunsen, mengambil biakan bakteri E. coli dan S. aureus menggunakan swap lalu digores pada cawan petri dengan goresan full dari arah kanan ke arah kiri cawan petri, goresan setengah dari cawan petri dilakukan sebanyak 3 kali dengan sisi yang berbeda dan pada goresan yang keempat dilakukan goresan full hingga menutupi seluruh permukaan medium. Metode difusi cakram dilakukan dengan menggunakan masing-masing 2 paper disk ditetesi dengan aquades untuk kontrol negatif, campuran tetracyclin dan aquades sebagai kontrol positif dan sampel untuk uji aktivitas. Diletakkan masing-masing 3 paper disk yang berbeda pada cawan petri biakan E. Coli dan S. aureus dan beri jarak. Cawan petri diwrap lalu dimasukkan kedalam inkubator dan setelah diinkubasi 24 jam, diamati zona bening pada setiap paper disk lalu diukur dengan mikrometer sekrup. Data hasil penelitian selanjutnya dianalisis menggunakan analisis deskriptif kualitatif untuk menggambarkan daya hambat ekstrak daun mahkota dewa terhadap pertumbuhan bakteri E. coli dan S. aureus.

\section{HASIL DAN PEMBAHASAN}

\section{A. Uji Fitokimia}

Hasil uji fitokimia daun mahkota dewa (Phaleria macrocarpa) dapat dilihat pada Tabel 1.

Tabel 1. Hasil uji fitokimia daun mahkota dewa

\begin{tabular}{ccc}
\hline $\begin{array}{c}\text { Identifikasi } \\
\text { senyawa }\end{array}$ & Hasil Uji & Keterangan \\
\hline $\begin{array}{c}\text { Alkaloid: } \\
\text { Wagner }\end{array}$ & - & Tidak terbentuk endapan \\
Mayer & - & \\
\hline Flavonoid & - & Tidak terjadi perubahan \\
\hline Tanin & + & Hijau kehitaman \\
\hline Saponin & - & Tidak terjadi perubahan \\
\hline Fenol & - & Tidak terjadi perubahan \\
\hline
\end{tabular}


Berdasarkan hasil uji fitokimia daun mahkota dewa yang terdapat pada Tabel 1. menunjukkan bahwa daun mahkota dewa mengandung tanin. Ini membuktikan daun mahkota dewa mengandung senyawa aktif metabolit sekunder. Pada pengujian tanin menunjukkan hasil positif dengan perubahan warna hijau kehitaman. Untuk uji alkaloid, flavonoid, saponin, dan fenol memberikan hasil negatif karena tidak adanya endapan maupun perubahan warna yang terjadi pada saat penambahan pereaksi. Kandungan tanin yang terkandung di dalam daun menunjukkan bahwa daun mahkota dewa berpotensi sebagai antioksidan.

Setelah didapatkan ekstrak dari daun P. macrocarpa dilakukan uji fitokimia. Menurut Novitasari (2016), uji fitokimia untuk tanaman obat sangat diperlukan, biasanya uji fitokimia digunakan untuk merujuk pada senyawa metabolit sekunder yang ditemukan pada tumbuhan yang tidak digunakan atau dibutuhkan pada fungsi normal tubuh. Namun memiliki efek yang menguntungkan bagi kesehatan atau memiliki peranan aktif bagi pencegahan penyakit. senyawa metabolit sekunder diproduksi oleh tumbuhan salah satunya untuk mempertahankan diri dari kondisi lingkungan yang kurang menguntungkan seperti suhu, iklim, maupun gangguan hama dan penyakit tanaman. Senyawa kimia yang bermanfaat dari tumbuhan adalah hasil dari metabolit sekunder. Senyawa metabolit sekunder ini dikelompokkan menjadi beberapa golongan berdasarkan stuktur kimianya yaitu alkaloid, flavonoid, steroid, tanin, saponin, dan terpenoid. Senyawa ini diantaranya berfungsi sebagai pelindung terhadap serangan atau gangguan yang ada disekitar, sebagai antibiotik, dan juga sebagai antioksidan (Atmoko dan Ma'ruf, 2009).

Uji fitokimia meliputi uji alkaloid, flavonoid, saponin, tanin/polifenol, terpenoid dan steroid. Uji ini dilakukan untuk mengidentifikasi senyawa metabolit sekunder yang terdapat pada ekstrak daun. Uji alkaloid yaitu reaksi pengendapan yang terjadi karena adanya penggantian ligan. Atom nitrogen yang mempunyai pasangan elektron bebas pada alkaloid dapat mengganti ion iod dalam pereaksi wagner dan pereaksi mayer. Alkaloid mengandung nitrogen sebagai bagian dari sistem sikliknya serta mengandung substituen yang bervariasi seperi gugus amina, amida, fenol, dan metoksi sehingga alkaloid bersifat semipolar (Hardiana, 2012). Uji alkaloid dilakukan menggunakan pereaksi Mayer (kalium tetraiodomerkurat, Wagner (iodin dalam kalium iodida) dan (bismut nitrat dalam kalium iodida). Sampel yang mengandung alkaloid akan membentukendapan jingga sampai kecoklatan dan terbentuk endapan apabila direaksikan dengan masingmasing dari ketiga reagen tersebut.

Identifikasi senyawa flavonoid dilakukan dengan menggunakan pereaksi serbuk magnesium $(\mathrm{Mg})$ dan asam klorida pekat $(\mathrm{HCl})$. Penambahan serbuk $\mathrm{Mg}$ bertujuan agar membentuk ikatan dengan gugus karbonil pada senyawa flavonoid. Penambahan $\mathrm{HCl}$ bertujuan untuk membentuk garam flavilium yang ditandai dengan perubahan warna menjadi merah jingga (Robinson, 1995; Ergina, dkk., 2014; Yanti \& Vera, 2019). Sedangkan Menurut Mega (2010), Flavonoid dan tanin merupakan senyawa polifenol yang memiliki sejumlah gugus hidroksi sehingga cenderung bersifat polar. Glikosida tersusun dari bagian glikon dan aglikon yang meliputi senyawasenyawa alkoholik, fenolik, isotiosianat, flavonoid serta steroid sehingga senyawa ini bersifat polar. Senyawa Saponin mengandung gugus glikosil yang berperan sebagai gugus polar serta gugus steroid dan triterpenoid yang berfungsi sebagai gugus nonpolar. Dan untuk Fenol adalah senyawa yang memiliki gugus hidroksil. 


\section{B. Uji Aktivitas Antimikroba}

Uji aktivitas antimikroba dilakukan untuk mengetahui adanya aktivitas antibiotik terhadap penghambatan pertumbuhan mikroba dilakukan dengan metode difusi cakram. Komponen kimia yang yang dievaluasi dari ekstrak daun P. macrocarpa akan kembali diujikan untu mengetahui apakah senyawa aktif yang terkandung dapat digunakan sebagai antimikroba. Uji antimikroba yang lebih spesifik dapat juga dilakukan terhadap bakteri-bakteri patogen (gram-positif dan gram-negatif). Contoh bakteri gram-positive yang dapat dipergunakan adalah S. aureus. Selain itu E. coli adalah contoh-contoh bakteri gram-negatif yang sering menjadi kultur uji dengan melihat respon hambatan yang diberikan oleh senyawa aktif dalam ekstrak sampel (Adila, dkk., 2013). Hasil uji aktivitas antimikroba ekstrak daun mahkota dewa terlihat pada Tabel 2.

Tabel 2. Hasil uji aktivitas antibakteri terhadap Staphylococcus aureus dan Escherichia coli

\begin{tabular}{lccc}
\hline \multicolumn{1}{c}{ Jenis Bakteri } & \multicolumn{3}{c}{ Diameter zona hambat } \\
\cline { 2 - 4 } & $\begin{array}{r}\text { Paper } \\
\text { disc 1 }\end{array}$ & $\begin{array}{l}\text { Paper } \\
\text { disc 2 }\end{array}$ & $\begin{array}{c}\text { Kontrol } \\
\text { positif }\end{array}$ \\
\hline E. coli & $0 \mathrm{~cm}$ & $0 \mathrm{~cm}$ & $0 \mathrm{~cm}$ \\
\hline S. aureus & $0,25 \mathrm{~cm}$ & $0,2 \mathrm{~cm}$ & $0 \mathrm{~cm}$ \\
\hline
\end{tabular}

Berdasarkan uji antimikroba ekstrak segar daun mahkota dewa menunjukkan bahwa ekstrak tersebut mampu menghambat pertumbuhan bakteri S. aureus ditandai dengan terbentuknya zona hambat pada perlakuan kontrol positif dan pada ekstrak sampel. Terbentuknya diameter zona hambat hal ini dikarenakan ekstrak daun mahkota dewa memiliki senyawa aktif yang bersifat sebagai antimikroba. Fiana \& Oktaria (2016) berpendapat bahwa daun mahkota dewa mengandung senyawa aktif diantaranya alkaloid, flavonoid, tanin, dan saponin.

Sedangkan pada cawan petri yang bersuspensi bakteri E.coli tidak terdapat zona hambat. Hal ini dikarenakan konsentrasi dari campuran larutan sangat rendah. Selain itu bakteri E. coli termasuk kedalam jenis bakteri gram negatif. Hal ini sesuai dengan pernyataan Octaviani, dkk., (2019) bahwa zona hambat bakteri gram positif lebih besar bila dibandingkan dengan bakteri gram negatif. Hal ini menunjukkan bahwa ekstrak lebih peka terhadap bakteri gram positif. Dalam hal ini, bakteri S. aereus merupakan bakteri gram positif yang lebih peka terhadap ekstrak, dibandingkan bakteri E. coli.

Adanya perbedaan aktivitas ini disebabkan karena perbedaan struktur dan komponen penyusun dinding sel bakteri. Lapisan peptidoglikan pada dinding sel bakteri gram negatif lebih tipis, sedangkan pada bakteri gram positif lapisan peptidoglikannya lebih tebal. Komponen penyusun dinding sel bakteri gram negatif lebih kompleks karena memiliki lapisan membran luar tambahan, sehingga akan lebih mudah menembus dinding sel Gram positif dibanding gram negatif. Pada perhitungan zona bening dari kedua cawan petri, dapat terlihat bahwa zona bening sampel pada biakan S. aereus untuk ekstrak sampel lebih luas dibanding kontrol positif.

Senyawa tanin pada ekstrak daun mahkota dewa bersifat (bakteriosidal) atau memiliki kemampuan merusak membran sel bakteri, dengan mengkerutkan dinding sel 
atau membran sel sehingga mengganggu permeabilitas sel itu sendiri. Akibat terganggunya permeabilitas, sel tidak dapat melakukan aktivitas hidup, sehingga terjadi koagulasi protoplasma bakteri kemudian pertumbuhannya terhambat bahkan mati. Tanin merupakan senyawa yang mampu membentuk zat besi, sehingga menimbulkan gangguan pada membran sel bakteri. Pada bakteri aerob, zat besi sangat dibutuhkan untuk melakukan berbagai fungsi, seperti pengurangan perkusor ribonukleotida pada DNA, dan pembentukan haem (Safitri, 2017). Hal ini menunjukan bahwa ekstrak daun mahkota dewa dapat digunakan sebagai antimikroba.

\section{KESIMPULAN}

Berdasarkan hasil penelitian ekstrak daun mahkota dewa dapat disimpulkan bahwa ekstrak daun mahkota dewa mengandung senyawa tannin memiliki kemampuan dapat menghambat pertumbuhan bakteri. Ekstrak daun mahkota dewa lebih efektif dalam menghambat pertumbuhan bakteri Staphylococcus aureus dibandingkan bakteri Esherechia coli yang ditunjukkan dengan zona hambat yang lebih besar. Hal ini berarti bahwa ekstrak daun mahkota dewa dapat digunakan sebagai bahan obat untuk penyakit yang disebabkan oleh bakteri S. aureus.

\section{DAFTAR PUSTAKA}

Adila, R., \& Nurmiati, \& Agustien. A. (2013). Uji Antimikroba Curcuma spp. terhadap Pertumbuhan Candida albicans, Staphylococcus aureus dan Escherichia coli. Jurnal Biologi Universitas Andalas, 2(1): 1-7.

Agustina, A. (2017). Uji Aktivitas Senyawa Antioksidan dari Ekstrak Daun Tiin (Ficus carica linn) dengan Pelarut Air, Metanol dan Campuran Metanol-Aireva. Klorofil 1(1): 3847.

Allen, Y., Agresa, F.L., \& Yuliandra, Y. (2017). Analisis Kromatografi Lapis Tipis (KLT) dan Aktivitas Antihiperurisemia Ekstrak Rebung (Schizostachyum brachycladum Kurz (Kurz) pada Mencit Putih Jantan. Jurnal Sains Farmasi dan Klinis. 3(2): 146-152. doi: 10.29208/jsfk.2017.3.2.141.

Atmoko, T., \& Ma'ruf, A. (2009). Uji Toksisitas dan Skrining Fitokimia Ekstrak Tumbuhan Sumber Pakan Orangutan Terhadap Larva Artemia Salina L. Jurnal Penelitian dan Konservasi Alam. 6(1): 37-45.

Ergina, Nuryanti, S., \& Pursitasari, I. D. (2014). Uji Kualitatif Senyawa Metabolit Sekunder pada Daun Palado (Agave angustifolia) yang Diekstraksi Dengan Pelarut Air dan Etanol, Jurnal Akademika Kimia, 3(3): 165-172.

Feliana, K., Mursiti, S., \& Harjono. (2018). Isolasi dan Elusidasi Senyawa Flavonoid dari Biji Alpukat (Persea americana Mill.). Indonesian Journal of Chemical Science, 7(2): 152159.

Fiana, N., \& Oktaria, D. (2016). Pengaruh Kandungan Saponin dalam Daging Buah Mahkota Dewa (Phaleria macrocarpa) terhadap Penurunan Kadar Glukosa Darah. Majority, 5(4): 128-132.

Novitasari, A. E., \& Putri, D.Z. (2016). Isolasi dan Identifikasi pada Ekstrak Daun Mahkota Dewa dengan Ekstraksi Maserasi. Jurnal Sains, 6(12): 10-14.

Hardiana., R., Rudiyansyah, \& Zaharah, T.A. (2012). Aktivitas Antioksidan Senyawa Golongan Fenol dari Beberapa Jenis Tumbuhan Famili Malvaceae. Jurnal Kimia Khatulistiwa, 1(1): 8-13.

Harmita \& Radji, M. (2008). Analisis Hayati Buku Ajar Program Studi Farmasi Universitas Indonesia. Jakarta: ECG. 
Ibrahim, A., \& Rusli, R. (2010). Potensi Antibakteri ekstrak Diethyl ether daun Mahkota Dewa (Phaleria macrocarpa (scheff.) Boerl) terhadap Bakteri Pseudomonas aeruginosa dan Staphylococcus aureus. Journal of Tropical Pharmacy and Chemistry, 1(1): 17-23. https://doi.org/10.25026/jtpc.v1i1.4.

Mega, I.M., \& Dewa, A.S. (2010). Screening Fitokimia dan Aktivitas Antiradikal bebas Ekstrak Metanol Daun Gaharu (Gyrinops vesteegii). Jurnal Kimia, 4(2): 187-192.

Nuria, M.C., Arvin Faizatun, Sumantri. Uji Aktivitas Antibakteri Ekstrak Etanol Daun Jarak Pagar (Jatropha curcas L) terhadap Bakteri Staphylococcus aureus Atcc 25923, Escherichia coli Atcc 25922, dan Salmonella typhi Atcc 1408. Jurnal Ilmu-ilmu Pertanian, 5(2): 26-37.

Octaviani, M., Fadhli, H., \& Yuneistya, E. (2019). Uji Aktivitas Antimikroba Ekstrak Etanol dari Kulit Bawang Merah (Allium cepa L.) dengan Metode Difusi Cakram. Pharmaceutical Sciences and Research, 6(1): $62-68$.

Robinson,T. (1995). Kandungan organik tumbuhan tinggi. Bandung: ITB Press.

Safitri, V., Hastutiek, P., \& Arimbi. (2017). Identifikasi Bakteri pada Eksoskeleton Lalat di Beberapa Pasar di Surabaya Identification of Bacteria on the Fly Exoskeleton in Some Markets in Surabaya. Journal of Parasite Science. 1(1): 1-6.

Sari, K.I.P., \& Periadnadi, N.N. (2013). Uji Antimikroba Ekstrak Segar Jahe-Jahean (Zingiberaceae) terhadap S. aureus, E. coli dan Candida albicans. Jurnal Biologi Universitas Andalas, 2(1): 20-24.

Susanty, S., \& Bachmid, F. (2016). Perbandingan Metanol Ekstraksi Maserasi dan Refluks terhadap kadar fenolik dari Ekstrak Tongkol Jagung (Zea mays L.). Konversi, 5(2): 87-93.

Suzery, M., Sri, L., \& Bambang, C. (2010). Penentuan Total Antosianin dari Kelopak Bunga Rosela (Hibiscus sabdariffa L.) dengan Metode Maserasi dan Sokshletasi. Jurnal Sains \& matematika, 18(1): 1-6.

Yanti, S., \& Vera, Y. (2019). Skrining Fitokimia Ekstrak Daun Belimbing Wuluh (Averrhoa Bilimbi). Jurnal Kesehatan Ilmiah Indonesia, 4(2): 41-46. 